\title{
Positive photoblastic response of seed germination in Eriosyce subgen. Neoporteria (Britton \& Rose) Helmut Walter (Cactaceae)
}

\section{Respuesta fotoblástica positiva en la germinación de semillas en Eriosyce subgen. Neoporteria (Britton \& Rose) Helmut Walter (Cactaceae)}

\author{
Pablo C. Guerrero, lua Alves-Burgos, Francisco T. Peña-Gómez \& Ramiro O. Bustamante \\ Departamento de Ciencias Ecológicas - Instituto de Ecología y Biodiversidad, Facultad de Ciencias, Universidad de Chile, \\ Casilla 653, Santiago, Chile. \\ pablo.c.guerrero@gmail.com
}

\section{RESUMEN}

Realizamos un experimento de laboratorio para evaluar el efecto de la luz blanca en la germinación de cinco taxa de Eriosyce subgen. Neoporteria. Todas las taxa germinaron profusamente con presencia de luz, mientras que en oscuridad casi no se registró germinación. Se discute que este rasgo fisiológico podría ser una respuesta conservada en el grupo Neoporteria.

\section{INTRODUCTION}

Seed germination is a complex process as it determines the potential of a plant for reproduction and persistence (Fenner \& Thompson 2005). In cacti, germination has proven to be particularly complex, as it can respond to different arrays of abiotic factors. In terms of light exposure, photoblastism is the germinative response of seeds to light (Fenner \& Thompson 2005). Seeds of Cactaceae species are either positively photoblastic (germination stimulated by light) or indifferent to light (Rojas-Aréchiga et al. 1997; Flores et al. 2006); negative photoblastism (germination inhibition) seems to be a non-existent germinative response in cacti. The explanations for such differential responses of seed germination to light intensity are diverse; while some studies invoke a relationship between photoblastic germination with life forms of cactus species (Rojas-Aréchiga et al. 1997), or seed size (Flores et al. 2006; Ortega-Baes et al. 2010) other suggest phylogenetic constraints (Ortega-Baes et al. 2010).

Besides the theoretical importance of elucidating the causes that have shaped the evolution of germinative responses, the Chilean cacti are recognized as a highly diverse and endangered lineage worldwide (Ortega-Baes \& Godínez-Alvarez 2006). The understanding of regeneration niche requirements of species urge for ex situ conservation and population restoration. For example incorrect essays (with unsuitable germination conditions) can be interpreted erroneously as low viability of seeds in the seedbank reservoirs. Indeed, inappropriate in situ essays determine low germination percentages in the field, resulting in low establishment of individuals, and therefore, unsuccessful population restoration (a critical aspect in endangered species).

The knowledge of seed germination of Chilean cacti is extremely poor. A search in the ISI Web of Science database (29 June 2010) including "Cactaceae" AND "germination" AND "Chile" retrieved zero published studies, while for Mexican cacti the same search found 47 published studies. The aim of this article is to contribute to the knowledge of the regeneration biology of Chilean cacti. Our specific objective was to determine the effects of white light on the seed germination on species of the endemic and monophyletic Eriosyce subgenera Neoporteria (Britton \& Rose) Helmut Walter. This study is of particular interest because most of the members of this lineage are considered to have conservation problems (Table I).

\section{MATERIALS AND METHODS}

We studied Eriosyce chilensis (Hildm. ex K. Schum.) Katt., E. subgibbosa (Haw.) Katt. var. subgibbosa, E. subgibbosa var. castanea (F. Ritter) Katt., E. subgibbosa var. litoralis (F.Ritter) Katt., and E. subgibbosa subsp. wagenknechtii (F. Ritter) Katt. Seeds of these species were collected from natural populations in central Chile (Table I) from mature fruits obtained from more than 10 individuals per species between October and December 2009. Fruits are mature 
when they are easily extracted from the mother plant and seeds fall off from the basal abscission. We pooled the seeds in a single paper bag per species and maintained them in dry conditions until the experiment was started in April 2010.

To assess the effect of light on seed germination we used the same protocol for the five taxa: 10 seeds were sown in a Petri dish ( $\mathrm{n}=20$ Petri dishes per species) on a substrate of $2 \mathrm{~g}$ of vermiculite and placed in a germination chamber with a photoperiod of $12 / 12 \mathrm{~h}$ and $21 / 16^{\circ} \mathrm{C}$ (day/night, respectively). Temperatures and day/night regimes were chosen based on our previous experience that showed the highest germination in Neoporteria at those conditions. Both treatments were watered only once at the beginning of the experiment. White light was generated by fluorescent lamps $(400-700 \mathrm{~nm})$ with a light intensity of $28.20 \mu \mathrm{mol}$ $\left(\mu \mathrm{mol} \mathrm{s}{ }^{-1} \mathrm{~m}^{-2}\right)$. For each species, dark conditions were simulated by covering 10 Petri dishes with aluminum paper; light conditions consisted of 10 uncovered Petri dishes. Once a week, we registered the germinated seeds only in the uncovered dishes, and when germination stabilized (i.e. no more germinated seeds were registered) we stopped the experiment and counted both covered and uncovered germinated seeds (this occurred after 5 weeks). Viability of seeds was evaluated with two methods: 1- seeds exposed to dark treatment (which showed much less germination) were relocated under white light and registered their germination (all species germinate equivalently to the light condition); 2- seeds were considered to be viable if in the end of the experiment they maintained their hardness and the embryos were white and turgid. All seeds were viable using these criteria. We did not conduct phylogenetic statistical analyses between species, because phylogenetic relationships of Neoporteria are not fully resolved and therefore comparisons should be not independent between each other.

TABLE I: Taxa used in this study (ordered from north to south), acronyms, seed origin and the conservation categories from three evaluations. According to the taxonomic classification a taxon can have more than one conservation category.

TABLA I: Taxa utilizados en este estudio (ordenados de norte a sur), el origen de las semillas y el estado de conservación de acuerdo a tres evaluaciones. Según la clasificación taxonómica un taxón puede poseer más de un estado de conservación.

\begin{tabular}{|c|c|c|c|}
\hline Taxa & Acronyms & Seed origin & Conservation status \\
\hline E. subgibbosa subsp. wagenknechtii (F. Ritter) Katt. & E_subgibbosa_wag & $\begin{array}{l}\text { Quebrada Juan Soldado } \\
(-29.65 \mathrm{~S} /-71.30 \mathrm{~W})\end{array}$ & $\begin{array}{l}\text { Rare }^{2} \\
\text { Vulnerable }\end{array}$ \\
\hline E. subgibbosa var. litoralis (F.Ritter) Katt. & E_subgibbosa_lit & $\begin{array}{l}\text { Quebrada El Teniente } \\
(-31.42 \mathrm{~S} /-71.6)\end{array}$ & Vulnerable $1,2,3$ \\
\hline E. chilensis (Hildm. ex K. Schum.) Katt. & E_chilensis & $\begin{array}{l}\text { Los Molles } \\
(-32.13 \mathrm{~S} /-71.53 \mathrm{~W})\end{array}$ & $\begin{array}{l}\text { Vulnerable }{ }^{1} \\
\text { Endangered }^{1,2,3}\end{array}$ \\
\hline E. subgibbosa (Haw.) Katt. var. subgibbosa & E_subgibbosa_sub & $\begin{array}{l}\text { Punta Lobos } \\
(-34.43 \mathrm{~S} /-72.05 \mathrm{~W})\end{array}$ & $\begin{array}{l}\text { Out of danger }{ }^{1,2} \\
\text { Vulnerable }^{2,3}\end{array}$ \\
\hline E. subgibbosa var. castanea (F. Ritter) Katt. & E_subgibbosa_cas & $\begin{array}{l}\text { Sagrada Familia } \\
(-35.12 \text { S/-71.62 W) }\end{array}$ & $\begin{array}{l}\text { Vulnerable }{ }^{1-3} \\
\text { Endangered }^{2}\end{array}$ \\
\hline
\end{tabular}

${ }^{1}$ Hoffmann \& Flores (1989); ${ }^{2}$ Belmonte et al. (1998); ${ }^{3}$ Hofmann \& Walter (2004).

\section{RESULTS}

Only E. subgibbosa var. litoralis germinated in darkness ( $3 \pm 2 \%)$; however, under light conditions, this species exhibited one of the highest germination levels $(93 \pm 2$ $\%$; Mann-Whitney U-test $\mathrm{P}<0.001$, Fig. 1). The rest of the species showed zero germination under dark conditions. Germination levels under light conditions were: Eriosyce chilensis $(93 \pm 4 \%)$, E. subgibbosa subsp. wagenknechtii $(88 \pm 5 \%)$, E. subgibbosa var. subgibbosa $(81 \pm 4 \%)$, and $E$. sugibbosa var. castanea $(60 \pm 5 \%)$ (Fig. 2).

\section{DISCUSSION}

Like other cacti, Eriosyce subgen. Neoporteria showed a positive photoblastic germination response. Similar results have been reported for 12 Argentinean Echinopsis Zucc. species (Ortega-Baes et al. 2010), the Bolivian and Argentinean Trichocereus terscheckii (J.Parm. ex Pfeiff.) Britton \& Rose (Ortega-Baes \& Rojas-Aréchiga 2007), and many Mexican species (Rojas-Aréchiga et al. 1997; RojasAréchiga \& Vásquez-Yanez 2000; Flores et al. 2006). As this germination response was observed in all taxa evaluated here (ancestral and derivate), we suspect that it might be a conserved trait within the Neoporteria clade. 
In general, cactus species are either positively photoblastic or indifferent to light (Benítez-Rodríguez et al. 2004; Flores et al. 2006; Ortega-Baes \& Rojas-Aréchiga 2007; Rojas-Aréchiga et al. 1997; Rojas-Aréchiga \& Vázquez-Yanes 2000). Although E. subgibbosa var. litoralis presented some germination in darkness, it was extremely low, and we still considered the response of this species as positive photoblastic due to the remarkable germination differences between treatments.

The positive photoblastism in small seeds may be related to the ability to form persistent seed banks (Bowers 2000; Flores et al. 2006; Rojas-Aréchiga \& Batis 2001), if Eriosyce subgen. Neoporteria form persistent seed banks remains unknown. However, preliminary field research in one species analysed in this study (i.e. E. subgibbosa var. subgibbosa) and the basal species of Neoporteria (i.e. Eriosyce chilensis) showed that all fruits and an important percentage (80\%$100 \%$ ) of seeds remains above apical areoles of parental plants even several months after ripening, supporting the idea that this group may form persistent seed banks.

Our results are of special interest for conservation management, since the high germination detected across species support the possibility of successful ex situ propagation programs, particularly for most endangered species, many of which grow in arid environments where recruitment could be very limited and episodic.

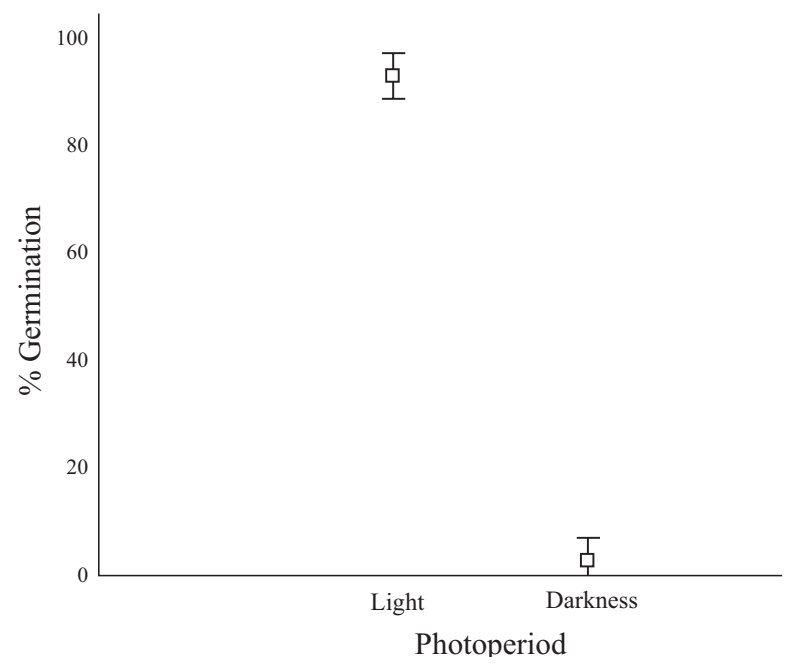

FIGURE 1. Germination of E. subgibbosa var. litoralis under white light and darkness (this taxon was the single one that presented some germination in darkness). Vertical lines show mean \pm 1.96 S.E.

FIGURA 1. Germinación de E. subgibbosa var. litoralis bajo luz blanca y oscuridad (este taxón fue el único en presentar algo de germinación en oscuridad). Las líneas verticales muestran la media \pm 1,96 E.E.

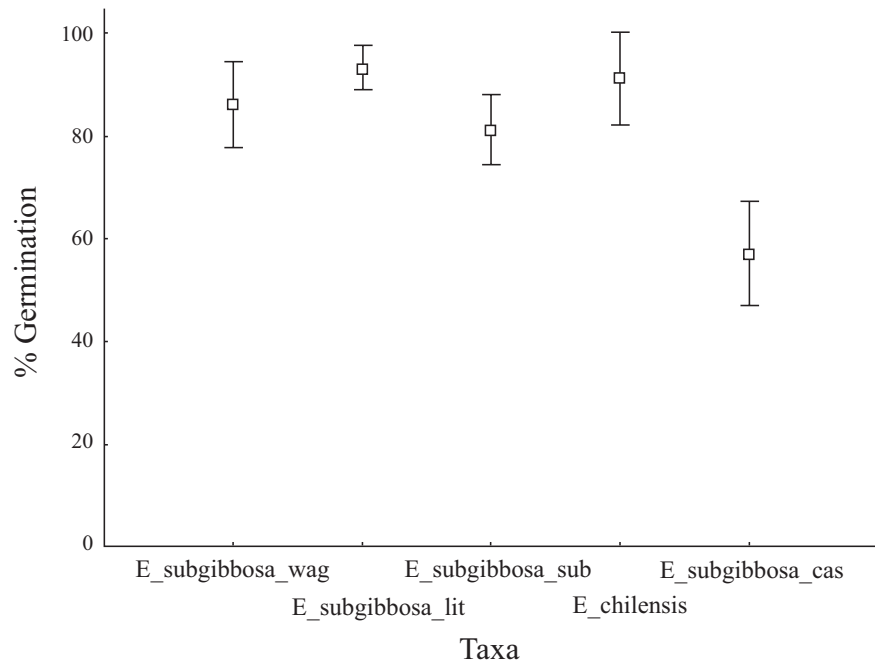

FIGURE 2: Germination of Eriosyce subgen. Neoporteria taxa under white light. Vertical lines show mean \pm 1.96 S.E.

Figura 2: Germinación de las taxa de Eriosyce subgen. Neoporteria bajo luz blanca. Las líneas verticales muestran la media \pm 1,96 E.E. 


\section{ACKNOWLEDGMENTS}

PCG acknowledges the support of CONICYT (D-21070301, AT-24090076, 75100024) and Fulbright (15103515). ROB acknowledges the support of ICM-P05-002.

\section{BIBLIOGRAPHY}

Belmonte, E., L. Faúndez, J. Flores, A. Hoffmann, M. Muñoz \& S. TeILlier.1998. Categorías de conservación de cactáceas nativas de Chile. Boletín Museo Nacional de Historia Natural 47: 69-89.

Benítez-Rodríguez, J., L. A. Orozco-Segovia, M. Rojas-Aréchiga. 2004. Light effect on seed germination of 4 Mammillaria species from the Tehuacán-Cuicatlán Valley, Central México. The Southwestern Naturalist 49: 11-17.

BowERS, J.E. 2000. Does Ferocactus wislizenii have a between-year seed bank? Journal of Arid Environments 45: 197-205.

Fenner, M. \& K. Thompson. 2005. The ecology of seeds. Cambridge University Press. 260 pp.

Flores, J., E. Jurado \& A. Arredondo. 2006. Effect of light on germination of seeds of Cactaceae from the Chihuahuan Desert, Mexico. Seed Science Research 16: 149-155.

Hoffmann, A.E. \& A.R. Flores. 1989. El estado de conservación de las plantas suculentas chilenas: Una evaluación preliminar.
En I. Benoit (ed.), Libro rojo de la flora terrestre de Chile, pp. 107-121. Corporación Nacional Forestal. Santiago, Chile.

Hoffmann, A.E. \& H.E. Walter. 2004. Cactáceas en la flora silvestre de Chile, Segunda Edición, Ediciones Fundación Claudio Gay, Santiago, Chile. 307 pp.

Ortega-Baes, P. \& H. Godínez-Alvarez. 2006. Global diversity and conservation priorities in the Cactaceae. Biodiversity and Conservation 15: 817-827.

Ortega-Baes, P. \& M. Rojas-Aréchiga. 2007. Seed germination of Trichocereus terscheckii (Cactaceae): light, temperature and gibberellic acid effects. Journal of Arid Environments 69: 169-176.

Ortega-Baes, P., M. Aparicio-González, G. Galíndez, P. del Fueyo, S. SÜHRING \& M. RoJAs-Aréchiga. 2010. Are cactus growth forms related to germination responses to light? A test using Echinopsis species. Acta Oecologica 36: 339-342.

RoJAS-ArÉchigA, M. \& A.I. BATIS. 2001. Las semillas de cactáceas. ¿forman bancos en el suelo? Cactáceas y Suculentas Mexicanas 46: 76-82.

Rojas-Aréchiga, M., A. Orozco-Segovia \& C. VÁzquez-Yanes. 1997. Effect of light on germination of seven species of cacti from the Zapotitlán Valley in Puebla, México. Journal of Arid Environments 36: 571-578.

Rojas-Aréchiga, M. \& C. VÁzquez-Yanes. 2000. Cactus seed germination: a review. Journal of Arid Environments 44: 85-104.

Recibido: 14.09 .10

Aceptado: 19.11 .10 